\title{
The Ideological Malleability of Corruption. A Comparative Analysis of Official Corruption Discourses in Albania and Colombia, 2010-2017
}

\begin{abstract}
Corruption literature has paid little attention to the way corruption discourses reflect specific ideological agendas. This paper aims to address such shortcoming by comparing official corruption discourses in Albania and Colombia during the last seven years. The paper shows that despite similar levels of corruption, the leaders of the two countries articulate corruption in slightly different ways. While the prime minster of Albania Edi Rama articulates corruption narrowly as bribery, a phenomenon that pertains almost exclusively to the public sector, president Juan Manuel Santos of Colombia articulates it more broadly as a phenomenon that has moral, ethical and cultural dimensions, which can also originate in the private sector although more pervasive in the public one. Based on the findings of this paper, these divergent articulations reflect ideological variations between the two leaders more than different corruption 'realities' on the ground.
\end{abstract}

Blendi Kajsiu is an Assistant Professor of Political Science in the Faculty of Law and Political Science at the University of Antioquia in Medellin, Colombia.

\section{Introduction}

There is an implicit recognition in the corruption literature that the definition of corruption is ideological insofar as corruption implies deterioration from an ideal political condition. As Mark Philp has pointed out, the reason why there has been no consensus on the definition of political corruption is due to the fact that 'the concept is rooted in ways of thinking about politics - that is, of there being some 'naturally sound condition' (variously described) from which corrupt acts deviate. ${ }^{1}$ In other words, the way one defines corruption implicitly reflects the ideal political condition that one holds dear. For example, Mark Warren defined corruption as 'duplicitous exclusion' since '[i]deally, democracy requires that every individual potentially affected by a collective decision should have

1 Mark Philp, Defining Political Corruption, Political Studies 45, no. 3 (1997), 436-462, 446, DOI: 10.1111/1467-9248.00090. All internet references were accessed on 27 April 2018. 
an opportunity to affect the decision, proportionally to his or her stake in the outcome'. ${ }^{2}$ For Marxist authors such as Stefan Sullivan, on the other hand, corruption expressed the inherent contradiction between the egalitarian necessity of democracy and the inherent tendency of capitalism to produce inequality, which is why it was defined as 'the vulnerability of states to market forces, to the power of capital, to the influence of wealthy voters and interest groups' ${ }^{3}$

Yet little attention has been paid to this aspect of corruption in the literature. While the majority of corruption literature has focused on the causes, the consequences and the eradication of corruption, fewer authors have analysed the way corruption discourses reflect specific ideological perspectives. A number of authors have shown how anti-corruption discourses reflected and legitimised a neoliberal order. ${ }^{4}$ While interesting, such analyses fail to explain the multiplicity of articulations of corruption within the broader neoliberal hegemony. This is why it is important to compare and contrast articulations of corruption by political actors in countries with similar levels of corruption in order to show how their ideological positions shape their articulation of this phenomenon.

Hence this paper compares official discourses in two countries, namely Albania and Colombia, which according to most international measures and observers suffer from similar high levels of corruption. This paper shows that despite similar levels of corruption the leaders of the two countries articulate corruption in slightly different ways. While the prime minster of Albania Edi Rama articulates corruption narrowly as bribery, a phenomenon that pertains almost exclusively to the public sector, president Juan Manuel Santos of Colombia articulates it more broadly as a phenomenon that has moral, ethical and cultural dimensions, which can also originate in the private sector, although it is far more present in the public one. I argue that such different articulations reflect ideological differences between the two leaders more than different corruption 'realities' on the ground. The articulation of corruption by president Santos as a phenomenon that is present both in the public and the private sector, although more in the former than in the latter, is a reflection of his Third

2 Mark E. Warren, Democracy and Deceit. Regulating Appearances of Corruption, American Journal of Political Science 50, no. 1 (2006), 160-174, 165, DOI: 10.1111/j.1540-5907.2006.00176.x.

3 Stefan Sullivan, Marx for a Post-Communist Era. On Poverty, Corruption, and Banality. London, New York 2002.

${ }^{4}$ See for example Pinar Bedirhanoğlu, The Neoliberal Discourse on Corruption as a Means of Consent Building. Reflections from Post-Crisis Turkey, Third World Quarterly 28, no. 7 (2007), 1239-1254, DOI: 10.1080/01436590701591770; Ed Brown / Jonathan Cloke, Neoliberal Reform, Governance and Corruption in the South. Assessing the International Anti-Corruption Crusade, Antipode 36, no. 2 (2004), 272-294, DOI: 10.1111/j.1467-8330.2004.00406.x; Barry Hindess, Review Essay. Investigating International Anti-Corruption, Third World Quarterly 26, no. 8 (2005), 1389-1398, http://www.jstor.org/stable/4017720; Sarah Bracking, Political Development and Corruption. Why 'Right Here, Right Now!?', in: Sarah Bracking, ed, Corruption and Development. The Anti-Corruption Campaigns, New York 2007, 3-28. 
Way ideology that while prioritising the market does recognise its limits and the need for state intervention. Prime minister Rama's articulation of corruption as primarily a public sector phenomenon, on the other hand, reflects his neoliberal ideology that sees the private sector as the engine of development and the state as a potential hindrance.

Although the neoliberal ideology is clearly dominant in both countries, different historical contexts have produced varying versions of such dominant ideology in each of them. In the case of Colombia the dominant Third Way ideology that Colombian president Juan Manuel Santos (2010-2018) articulated should be understood within the broader Latin American context where various social and political movements have strongly resisted the neoliberal project. ${ }^{5}$ While in the case of Colombia such resistance has been weaker than in the neighbouring countries (e.g. Bolivia, Ecuador and Venezuela) it has nevertheless been significant. ${ }^{6}$ As a consequence, political elites in Colombia moderated their neoliberal ideology - even while implementing it - by at times criticising the market and recognising the importance of state intervention when necessary, or by paying lip-service to left-wing concepts such as social justice. In the case of Eastern Europe, on the other hand, resistance to the neoliberal project has been much weaker, especially at the elite level. ${ }^{7}$ As some authors have argued when faced with neoliberal reforms in the 1990s, Eastern European societies were far more patient than 'the rebellious Latin American countries'. ${ }^{8}$ This was particularly the case in Albania, where a traumatic communist past could be easily utilised by local and international elites to legitimise a fundamentalist neoliberal ideology that saw the market as the new salvation. ${ }^{9}$

In order to prove the above argument, this paper has been organised in three main parts. In the first, I develop a theoretical and methodological framework that analyses corruption from a discourse analysis perspective, building on the insights of Ernesto Laclau and Chantal Mouffe. In the second, I compare qualitatively and quantitatively those speeches of Albanian prime minister Edi Rama and Colombian president Juan Manuel Santos that focus on, or mention, corruption, as well as their anti-corruption strategies and policies. In the third

${ }^{5}$ Richard L. Harris, Popular Resistance to Neoliberalism and Globalization in Latin America, Journal of Developing Societies 19, no. 2-3 (2003), 365-426, DOI: 10.1177/0169796X0301900209.

${ }^{6}$ Paul A. Chambers, Resisting Neoliberalism in Colombia. The Role of Human Rights, Latin American Perspectives 44, no. 5 (2017), 127-144, DOI: 10.1177/0094582X17699914.

7 Sonia Hirt / Christian Sellar / Craig Young, Neoliberal Doctrine Meets Eastern Bloc. Resistance, Appropriation and Purification in Post-Socialist Spaces. Europe-Asia Studies 65, no. 7 (2013), 1243-1254, 1245, DOI: 10.1080/09668136.2013.822711.

8 Béla Greskovits, The Political Economy of Protest and Patience. East European and Latin American Transformations Compared, Budapest 1998, 15.

${ }^{9}$ Blendi Kajsiu, Polarization without Radicalization. Political Radicalism in Albania in Comparative Perspective, Journal of Contemporary European Studies 24, no. 2 (2016), 280-299, 288, DOI: 10.1080/14782804.2016.1159545. 
and final part, I account for the different articulations of corruption by emphasising the different ideological contexts within which they have taken place.

\section{A Theoretical and Methodological Framework. A Discourse Analysis of Corruption}

Following Laclau and Mouffe, discourse is understood as a symbolic order that 'includes within itself the linguistic and the nonlinguistic' ${ }^{10}$ Hence, all objects are constituted as objects of discourse. In the case of corruption this means that instead of looking for an essence of this phenomenon, the different signifieds will be traced that were attached to the signifier corruption in the Albanian and Colombian contexts. Here, the analytical distinction will be followed made by Ferdinand de Saussure between the signifier and the signified, where the signifier is the sound-image, whereas the signified is the concept that the signifier stands for. ${ }^{11}$ By looking at corruption as a signifier, focus can be placed on the different signifieds (i.e. meanings, contents, concepts) that the signifier corruption has stood for in different contexts. This means that instead of trying to identify a common denominator, a minimal remainder, or a common essence of different signifieds that come under the signifier 'corruption', the aim here is to explore how the signifier 'corruption' connects with different signifieds in the Albanian and Colombian official corruption discourses.

To understand this process, the concept of 'floating signifier' will be utilised, which was developed by Laclau and Mouffe and consists of 'the sliding of the signified under the signifier' ${ }^{12}$ More specifically, a floating signifier is a 'signifier that is overflowed with meaning because it is articulated differently within different discourses' ${ }^{13}$ The signifier corruption has been attached to a number of different signifieds in different paradigms within political science. Thus, under the modernisation paradigm, corruption was seen as a consequence of a lack of modernisation and it was connected to bribery, misappropriation of public funds, nepotism, patronage and clientelism as 'behavior which deviates from the duties of a public role because of private regarding (personal, close family, private clique) pecuniary or status gain'. ${ }^{14}$ In the economic paradigm, corruption was connected to a lack of competition such as rent-seeking, or as the

10 Ernesto Laclau, New Reflections on the Revolution of Our Times, London, New York 1990, 100.

11 David Howarth, ed, Discourse, Buckingham 2000, 19.

12 Jacob Torfing, New Theories of Discourse. Laclau, Mouffe and Žižek, Oxford, Malden/ MA 1999, 62.

13 Torfing, New Theories of Discourse, 301.

14 Joseph S. Nye, Corruption and Political Development. A Cost-Benefit Analysis, American Political Science Review 61, no. 2 (1967), 417-427, 419, http://www.jstor.org/stable/1953254. 
Table 1. Corruption as a floating signifier.*

\begin{tabular}{|l|l|l|l|}
\hline Paradigm & Modernisation & Economic & Political \\
\hline Signifier & Corruption & Corruption & Corruption \\
\hline \multirow{3}{*}{ Signifieds } & Bribery & Rent-seeking & Betrayal of principal's interests \\
& $\begin{array}{l}\text { Clientelism } \\
\text { Lack of moder- } \\
\text { nisation }\end{array}$ & $\begin{array}{l}\text { by an agent } \\
\text { Lack of economic competition } \\
\text { State capture }\end{array}$ & $\begin{array}{l}\text { Unjustified disempowerment } \\
\text { and political participation } \\
\text { Contradiction between capital- } \\
\text { ism and democracy } \\
\text { Lack of democracy }\end{array}$ \\
\hline
\end{tabular}

* Cf. Blendi Kajsiu, A Discourse Analysis of Corruption. Instituting Neoliberalism Against Corruption in Albania, 1998-2005, Farnham, Burlington 2014, 9-29.

betrayal of a principal's interest by an agent. ${ }^{15}$ In the political paradigm, on the other hand, corruption has been connected to 'unjustifiable disempowerment' ${ }^{16}$ as well as to unjust patterns of economic and political participation, and to the incompatibility of 'economic and political systems, which is most acute in terms of the competing imperatives of capitalism and democracy' (see Table 1). ${ }^{17}$

As Table 1 shows, the signifier corruption has been attached to different signifieds in different discourses within political science. What Table 1 however does not show, is that corruption discourses are ideologically laden. They entail efforts to legitimise or neutralise specific social or political orders. This means that they will produce conceptions of corruption that not only reflect their ideological tendency but also tend to reinforce or reproduce them. Thus, the modernisation literature on corruption implied that the 'state apparatuses of Western Europe and the US allegedly operate[ed] according to rational procedures and universalistic principles in which there [was] no place for personalism, cronyism and, most of all the confusion of the private and public interests. ${ }^{18}$ Within the economic paradigm, on the other hand, public choice accounts of corruption 'favor[ed] a shift from politics to the market so as to make fewer demands on self-restraint'.$^{19}$ In this way most accounts of corruption within the economic paradigm have served to legitimise a neoliberal ideology of privatisation and marketisation. Finally, within the political paradigm different articulations of corruption reflect different ideological positions. Thus, for Marxist authors such as Stefan Sullivan, corruption referred to the 'vulnerability of states to market

\footnotetext{
15 Robert Klitgaard, ed, Controlling Corruption, Berkeley/CA, Los Angeles, London 1988, 24.

16 Mark E. Warren, Political Corruption as Duplicitous Exclusion, PS: Political Science and Politics 39, no. 4 (2006), 803-807, 804, http://www.jstor.org/stable/20451821.

17 John Girling, ed, Corruption, Capitalism and Democracy, London, New York 1997, 22.

18 Robin Theobald, Corruption, Development and Underdevelopment, London et al. 1990, 47.

19 Mark Philp, Defining Political Corruption.
} 
forces, to the power of capital, to the influence of wealthy voters and interest groups'. ${ }^{20}$

In order to avoid the above pitfalls, it is important to approach corruption from an anti-essentialist discourse analysis perspective that does not fall into any of the above three paradigms. Instead of trying to identify what corruption is, it is important to explore why corruption is defined or understood in a certain way. The aim here is to explain the articulation of corruption in terms of the function it performs within a political regime. To do so, one needs to approach corruption as a discursive construction whose definition constantly changes depending on the political ideals or the political agenda of those who articulate it. Approaching corruption as a discursive construction enables one to understand how and why it can be used to legitimise a given political agenda. As such, a discursive analysis of corruption allows the avoidance of the pitfall of conforming to a given political ideal under the guise of corruption analysis.

\section{Methodological Implications}

The above theoretical framework has two methodological implications. First, official discourse is not only understood as the speeches of the two respective leaders in Albania and Colombia, but also includes their anti-corruption strategies and policies as well as the legislation their governments have produced. The second methodological implication is that in order to account for the differences between the two official corruption discourses, the respective ideological contexts within which they take place need to be explored.

In order to emphasis the differences between the two official corruption discourses, a qualitative and a quantitative methodology has been pursued. From a qualitative approach, the discourses have been analysed in which the two heads of government tackle the issue of corruption directly or indirectly, as well as their respective anti-corruption strategies to identify how corruption was articulated within each discourse. From a quantitative approach, five mutually exclusive categories of articulation of corruption have been developed, which were used to codify the usage of the concept of corruption in the speeches of the two leaders (see Table 2).

After developing the codification, a sample of speeches was identified in which the two heads of government mentioned the word corruption at least twice, during the period 2014-2017. Within this population, a random sample of mentions of corruption was selected that was representative of the whole population. Every mention of corruption was analysed within the paragraph where it appeared to determine in which of the above categories the mention

20 Sullivan, Marx for a Post-Communist Era. On Poverty, Corruption and Banality, 100-101. 
Table 2. Five categories of corruption articulation .

\begin{tabular}{|l|l|}
\hline Category & Description \\
\hline $\begin{array}{l}\text { Public sector } \\
\text { corruption }\end{array}$ & $\begin{array}{l}\text { Corruption as a phenomenon that pertains to the public sector, this includes } \\
\text { the state, state institutions, public services such as education, health, police, } \\
\text { customs, and tax authorities, public enterprises, etc. }\end{array}$ \\
\hline $\begin{array}{l}\text { Private sector } \\
\text { corruption }\end{array}$ & $\begin{array}{l}\text { This includes corruption in the private sectors, principally businesses, society } \\
\text { associations, such as NGOs, the Media, and private foundations. }\end{array}$ \\
\hline $\begin{array}{l}\text { Public-Private } \\
\text { Corruption }\end{array}$ & $\begin{array}{l}\text { Corruption that results from the interaction between the private and the pub- } \\
\text { lic sector, through public procurement, the financing of political campaigns } \\
\text { by private agents, or state capture. }\end{array}$ \\
\hline $\begin{array}{l}\text { Cultural } \\
\text { Corruption }\end{array}$ & $\begin{array}{l}\text { Corruption as a cultural, moral or ethical phenomenon that involves the pub- } \\
\text { lic and the private sectors, as well as society as a whole. }\end{array}$ \\
\hline None & $\begin{array}{l}\text { Corruption as a phenomenon that does not fall into any of the above men- } \\
\text { tioned categories. }\end{array}$ \\
\hline
\end{tabular}

Source: Compilation of the author.

Table 3. Speeches and samples of corruption discourses for Rama and Santos.

\begin{tabular}{|l|l|l|}
\hline Head of Government & Juan Manuel Santos & Edi Rama \\
\hline Number of speeches that mention corruption & 40 & 44 \\
\hline Time Period & $2010-2017$ & $2014-2017$ \\
\hline Total number of words & 120000 & 178687 \\
\hline Total number of mentions of corruption & 363 & 372 \\
\hline Representative sample & 60 & 63 \\
\hline
\end{tabular}

Source: Compilation of the author.

belonged. Table 3 explains the population of speeches that mention corruption and the sample for each population.

\section{Official Discourses of Corruption in Albania and Colombia, 2010-2017}

There are three key differences in the articulation of corruption between Santos and Rama that pertain to its location, the type of victimisation it produces and its definition. In Rama's discourse, corruption is located primarily within the public sector in general and the state in particular, while it seems quite absent from the private sector. In Santos' discourse on the other hand, corruption can be found both in the private and the public sector, as well as in the interaction between the two. This leads to a second difference; the victimisation that corruption produces. While in Rama's discourse the state is the principal perpetrator of corruption and the private companies and citizens its primary victims; Santos 
also articulates corruption as perpetrated by private and social actors against the state. Finally, corruption is defined quite narrowly in Rama's discourse and more widely in that of Santos. While for Rama corruption is primarily defined as bribery, for Santos corruption is more than an economic transaction; it has a moral, ethical, cultural and social dimension as well.

\section{The Location of Corruption. The Public vs. the Private Sphere}

In Rama's discourse corruption was defined almost exclusively in terms of the failure of the state to provide services, to uphold free competition and meritocracy in the public administration. The citizens were forced to resort to corruption when the state did not provide the services they were entitled to. According to Rama:

'In the end corruption is nothing more, generally speaking, than the alternative to a service that the citizen expects from the state. If this service that the citizens expect from the state, and that the state has the obligation to offer, is slow, bad and leads to completely obscure procedures, then corruption appears as a quick and efficient alternative. ${ }^{21}$

In this context the elimination of corruption called for modernisation, so the state could guarantee quick, qualitative and transparent services to its citizens, a meritocratic public administration and a competitive free market. According to Rama,

' $[\mathrm{t}]$ he modern states do not have corruption in the form of an alternative to services. [...] The archaic states have corruption as an alternative to services and the answer is modernisation. ${ }^{22}$

It is interesting to note here that Rama combines the conceptions of corruption within the modernisation and the economic paradigms. From the modernisation perspective, corruption in Albania is identified with the lack of a modern state and the presence of dysfunctional and archaic (read: traditional) structures. From the economic perspective corruption is identified with the lack of a competitive market economy, since there is no room for corruption within a functioning market economy.

${ }^{21}$ The Speech of Prime Minister Edi Rama at the conference 'The Passport, Your Safety in Electronic Services', in: Kryeministra (Prime Minister's Office), Inovacion në shërbime për të luftuar korrupsionin, Tirana, 11 October 2014, http://www.kryeministria.al/al/newsroom/ lajme/inovacion-ne-sherbime-per-te-luftuar-korrupsionin/.

22 The Speech of Prime Minister Edi Rama at the conference on the War Against Corruption, organised by George C. Marshall Center, in: Kryeministra (Prime Minister's Office), Meritokraci, konkurrencë dhe shërbime përballë korrupsionit, Tirana, 23 September 2014, http:// kryeministria.al/newsroom/meritokraci-konkurrence-dhe-sherbime-perballe-korrupsionit/. 
As the above citations show, in Rama's discourse corruption in Albania was seen as primarily a public sector problem. It was this feature that, according to him, distinguished corruption in Albania from corruption in other developed European countries:

'If there is anything that distinguishes corruption in Albania from corruption in other countries of the European Union, it is the fact that corruption in Albania is endemic in every cell of the organism of the state, and in every contact of the state with the extended hand of the citizen who asks for a service. ${ }^{23}$

At times Rama did allude to corruption in the private sector, especially in the higher education sector, which included both public and private institutions. ${ }^{24}$ However, this happened very rarely. In Rama's discourse corruption was a problem overwhelmingly present in the public rather than the private sector.

This understanding of corruption informed the anti-corruption strategy produced by Rama's government in 2015. Its main aim was, ‘[t]ransparent Albanian institutions with high levels of integrity, which enjoy the trust of the citizens and guarantee incorruptible and high quality services. ${ }^{25}$ The main challenges that the anti-corruption efforts faced in Albania according to the strategy were:

- strengthening the integrity of public administration;

- reforming the judiciary and strengthening its independence;

- improving the quality of legislation;

- enhancing the stability of public administration;

- supporting independence and/or functioning autonomy of key institutions (executive and independent);

- addressing the lack of trust or inter-institutional cooperation. ${ }^{26}$

What the above list shows is that corruption challenges in Albania were confined to the state sector. Hence the aim of anti-corruption policies was 'eradicating corruption primarily in the public administration and all the state institutions and especially in institutions that offer services to the citizens' ${ }^{27}$ The strategy emphasised that the main aim was to strengthen transparency 'in all the fields

23 The Speech of Prime Minister Edi Rama at the conference 'The Presentation of the First Draft of the Anti-Corruption Strategy 2014-2017', in: Kryeministra (Prime Minister's Office), Aksion të fortë kundër plagës së korrupsionit, Tirana, 9 December 2013, https://kryeministria. al/newsroom/rama-aksion-te-forte-kunder-plages-se-korrupsionit/.

${ }^{24}$ The Speech of Prime Minister Edi Rama at the conference 'The Presentation of the First Draft of the Anti-Corruption Strategy 2014-2017'.

${ }^{25}$ Këshilli i Ministrave (Council of Ministers of Albania), Për miratimin e strategjisë mdërsektoriale kundër korrupsionit për periudhën 2015-2020, Decision 247, 20 March 2015, 11, http://www.qbz.gov.al/botime/fletore_zyrtare/2015/PDF-2015/47-2015.pdf.

${ }^{26}$ Këshilli i Ministrave (Council of Ministers of Albania), Për miratimin e strategjisë mdërsektoriale kundër korrupsionit për periudhën 2015-2020, 8 .

${ }^{27}$ Këshilli i Ministrave (Council of Ministers of Albania), Për miratimin e strategjisë mdërsektoriale kundër korrupsionit për periudhën 2015-2020, 11. 
of activity of the state, strengthening transparency with regard to political party financing as well as strengthening transparency and integrity with regard to public servants' ${ }^{28}$ Consequently, it should not come as a surprise that there were no provisions in the 2015 Albanian anti-corruption strategy on lobbying, state capture, or phenomena such as revolving doors between public and private sectors, despite the fact that as late as 2011 there were no statutory provisions in Albania in order to regulate lobbying or revolving door policies. ${ }^{29}$

By contrast, the Colombian official discourse while also articulating corruption primarily as a problem of the public sector, did also acknowledged quite explicitly that corruption originated in the private sector as well. President Santos explicitly emphasised that corruption involved 'the state as much as the private sector' ${ }^{30}$ For this reason Santos would declare that his government would fight with 'equal determination official or private corruption and the communicating channels between them'. ${ }^{31}$ The first implication here was that corruption resulted from the public-private interaction. As Santos pointed out, '[w]e know very well that corruption has two points: the public servant and the private individual. ${ }^{32}$ The second implication was that corruption also originated within the private sector itself. Phenomena such as collusion among private companies in order to fix their proposals in public procurement processes, or fiscal evasion were articulated by Santos as acts of corruption within the private sphere. His government set up an elite group that aimed 'to fight specifically collusion - which also is corruption - in public procurement. And

${ }^{28}$ Këshilli i Ministrave (Council of Ministers of Albania), Për miratimin e strategjisë mdërsektoriale kundër korrupsionit për periudhën 2015-2020, 11.

${ }^{29}$ Chari Raj / John Hogan / Gary Murphy, Council of Europe. European Commission for Democracy through Law (Venice Commission), The Legal Framework for the Regulation of Lobbying in the Council of Europe Member States, Study no. 590/2010, CDL-DEM(2011)002, Strasbourg, 31 May 2011, 5, http://www.venice.coe.int/webforms/documents/default.aspx?pdffile=CDL-DEM(2011)002-e.

30 The Speech of Juan M. Santos at the $13^{\text {th }}$ Annual Assembly of the Colombian American Chamber of Commerce, in: Presidencia de la República de Colombia, Palabras del Presidente Juan Manuel Santos en la LXIII Asamblea Anual de la Cámara de Comercio de Colombia Americana, Bogota, 28 March 2017, http://es.presidencia.gov.co/sitios/busqueda/ discursos/170328-Palabras-del-Presidente-Juan-Manuel-Santos-en-la-LXIII-Asamblea-Anual-de-la-Camara-de-Comercio-de-Colombia-Americana/Discursos.

31 Presidencia de la República de Colombia, Acceptance Speech of Juan Manuel Santos. The Time of Colombia in Now!, Bogota, 7 August 2010, http://wsp.presidencia.gov.co/Prensa/2010/ Agosto/Paginas/20100807_27.aspx.

32 The Speech of President Santos on the approval of the Anti-Corruption Statute, in: Presidencia de la República de Colombia, Palabras del Presidente Juan Manuel Santos en la sanción del Estatuto Anticorrupción, Bogota, 12 July 2011, http://wsp.presidencia.gov.co/Prensa/ 2011/Julio/Paginas/20110712_08.aspx. 
in the 2017 tax reform fiscal evasion - another way to rob the state-became a criminal violation.' 33

The fact that corruption was not understood as a phenomenon that originated only in the public sector was reflected in Santos' 2013 anti-corruption strategy, which aimed at fighting 'corruption in the public and the private sectors' ${ }^{34}$ The strategy defined corruption as 'the use of power in order to divert the administration of public goods towards private benefits. This implies that corrupt practices are realised by private or/and public actors with power and influence over the process of decision-making and the administration of public goods. ${ }^{35}$

The concern regarding corruption in the private sector was reflected in the objectives of the 2013 anti-corruption strategy that aimed, among other things, to include 'accountability as part of the culture of public and private organisations'. ${ }^{36}$ The strategy argued that from its perspective, 'the private sector was expected to adopt mechanisms that promote its co-responsibility in the prevention of corruption'. ${ }^{37}$ Such measures included 'the development of registers and systems of publicity, the dissemination of manuals on best practices as well as the recognition of successful experiences in transparency and the war against corruption'. ${ }^{38}$ In this context the Secretary of Transparency of the Presidency under the initiative 'Active Enterprises in the Implementation of Anti-Corruption' promoted the adoption of various transparency pacts and ethical codes of conduct within different sectors of the Colombian economy, such as the pharmaceutical, petrol, energy and insurance industries as well as the healthcare sector. ${ }^{39}$

Following the same logic, the Colombian Anti-Corruption Statute of 2011article 7 thereof-established new regulations that affected the private sector. It stipulated that public accountants had to denounce acts of corruption they

33 The Speech of President Santos at the ceremony where the new General Attorney Fernando Carillo was sworn into office, in: Presidencia de la República de Colombia, Palabras del Presidente Juan Manuel Santos en el acto de posesión del Procurador General de la Nación, Fernando Carrillo, Bogota, 16 January 2017, http://es.presidencia.gov.co/sitios/ busqueda/discursos/170116-Palabras-del-Presidente-Juan-Manuel-Santos-en-el-acto-de-posesion-del-Procurador-General-de-la-Nacion-Fernando-Carrillo/Discursos.

${ }^{34}$ Consejo Nacional de Política Económica y Social (CONPES), Estrategia Nacional de la Pólitica Pública Integral Anticorrupción, Departamento Nacional de Planificación, Presidencia de la Republica, Secretaria de Transparencia, Documento 167, Bogota, 9 December 2013, 57, http://www.anticorrupcion.gov.co/SiteAssets/Paginas/Publicaciones/Conpes_167.pdf.

35 CONPES, Estrategia Nacional de la Pólitica Pública Integral Anticorrupción, 18.

36 CONPES, Estrategia Nacional de la Pólitica Pública Integral Anticorrupción, 59.

37 CONPES, Estrategia Nacional de la Pólitica Pública Integral Anticorrupción, 68.

38 CONPES, Estrategia Nacional de la Pólitica Pública Integral Anticorrupción, 68.

39 Secretaria de Transparencia, Estatuto Anticorrupcion Ley 1474 de 2011. Avances y desafíos tras cinco años de su expedición, Presidencia de la Republica, Bogota 2016, 18, http:// www.anticorrupcion.gov.co/Documents/Publicaciones/estatuto-anticorrupcion-ley-1474-2011. pdf. 
were aware of, thereby eliminating the confidentiality clause in the cases of corruption in the private sector. ${ }^{40}$ It also introduced in article 18 penalties for insider-trading, treating this phenomenon as a manifestation of corruption within the private sector. The Anti-Corruption Statute defined insider-trading as a crime and stipulated 'imprisonment and monetary sanctions against employees, directors or members of the board of directors of a private entity that make inappropriate use of privileged information (which is not known to the public).' ${ }^{41}$

\section{The Public and Private Sectors. Victims and Perpetrators of Corruption}

The private sector in Rama's discourse appears primarily as the victim of corruption. This is not to say that the private sector is not involved in the process of corruption. It is, however, the public sector which forces the private sector to pay bribes through bureaucracy and lengthy procedures. Hence Rama's anticorruption strategy aimed to reduce

'contacts between the enterprises and the state. The greater the number of contacts and the larger the bureaucracy; the greater the number of impediments and the higher the level of corruption. The lower the number of contacts and the smaller the size of the bureaucracy; the fewer the number of impediments, the lower the level of corruption and the more freedom for the enterprises. ${ }^{42}$

It is interesting to notice that in the above reasoning, corruption seemed to be the result of impediments and the size of bureaucracy that the state created. In order to overcome this, the enterprises had to resort to corruption. They were passive and unwilling participants in a phenomenon that was perpetrated by public actors. Hence Rama's anti-corruption strategy promised that:

'There will be no more entrepreneurs obligated to pay; to pay and keep silent. To keep silent out of fear that if they speak, what they will have to pay increases and their tongue will be cut off completely. The opposite will happen! We consider every entrepreneur a partner in the process against this endemic corruption that appears in every contact between the entrepreneur and the [public] administration, as if it were a contact with the plague. ${ }^{43}$

40 Secretaria de Transparencia, Estatuto Anticorrupcion Ley 1474 de 2011. Avances y desafíos tras cinco años de su expedición, 11.

${ }^{41}$ Secretaria de Transparencia, Estatuto Anticorrupcion Ley 1474 de 2011. Avances y desafíos tras cinco años de su expedición, 17.

42 Edi Rama, Lufta kundër informalitetit do të sjellë rritjen e investimeve dher ulje të taksave, in: Kryeministra (Prime Minister's Office), Tirana, 23 October 2015, https://kryeministria.al/ newsroom/lufta-kunder-informalitetit-do-te-sjelle-rritjen-e-investimeve-dhe-ulje-te-taksave/.

${ }^{43}$ The Speech of Prime Minister Edi Rama at the reunion with businesses 'Dialogue, Responsibility, and Partnership', in: Kryeministra (Prime Minister's Office), Qeveria do t'ju 
It is important to notice that the plague in the above citation refers to the public administration that has terrorised private entrepreneurs through corruption. The same was true for private citizens in general. According to Rama, corruption was 'a system that everyday suck[ed] the blood of citizens and families, draining money from their pockets they should not have to spend on services they are entitled to by law and custom' ${ }^{44}$ Corruption here referred to the bribery that citizens needed to pay in order to receive a service. In this context, it was the state that was victimising and robbing the private citizen not vice versa.

This relationship was at times reversed in Santos' discourse. For him corruption sometimes was a process through which private individuals and companies robbed the state. According to Santos, the special regime that regulated contracts between the state and not-for-profit organisations 'was a preferred instrument for the corrupt to skim off the state. Foundations created or manipulated by corrupt people were and still are today being used to contract and rob the state, rob the citizens, to rob the public resources.' ${ }^{45}$ The major corruption scandal of the private multinational company Odebrecht in 2017 was articulated by Santos as an instance in which a private company did business 'corrupting public servants, gaining public contracts in an inappropriate way and doing inappropriate deals'.$^{46}$ Here the state was the victim, rather than the perpetrator of corruption.

As a consequence Santos, unlike Rama, would at times talk about state capture-a process in which the state was the victim rather than the perpetrator of corruption. He would declare in 2017 that the infrastructure sector, before his government came to power 'was captured by the corrupt' ${ }^{47}$ In response to

kërkojë pasi t'ju lajë borxhet, Tirana, 4 October 2013, https://kryeministria.al/newsroom/ qeveria-do-tju-kerkoje-pasi-tju-laje-borxhet/.

44 The Speech of Prime Minister Edi Rama at the conference on the War against Corruption, organised by the George C. Marshall Center.

${ }^{45}$ Declaration of President Santos after meeting with the Citizen Committee of the War Against Corruption and the National Committee of Moralization, in: Presidencia de la República de Colombia, Declaración del Presidente Juan Manuel Santos luego de las reuniones de la Comisión Ciudadana de Lucha contra la Corrupción y la Comisión Nacional de Moralización, Bogota, 23 January 2017, http://es.presidencia.gov.co/discursos/170123-Declaracion-del-Presidente-Juan-Manuel-Santos-luego-de-las-reuniones-de-la-Comision-Ciudadana-de-Luchacontra-la-Corrupcion-y-la-Comision-Nacional-de-Moralizacion.

46 The Speech of President Santos at the inauguration of the international terminal of the Palmira Airport, in: Presidencia de la República de Colombia, Palabras del Presidente Juan Manuel Santos en la inauguración de la nueva Terminal Internacional del Aeropuerto de Palmira, Presidencia de la República, Bogota, 8 March 2017, http://es.presidencia.gov.co/sitios/ busqueda/discursos/170309-Palabras-del-Presidente-Juan-Manuel-Santos-en-la-inauguracion-de-la-nueva-Terminal-Internacional-del-Aeropuerto-de-Palmira/Discursos.

47 The Speech of President Santos at the inauguration of the overpass Fuente, in: Presidencia de la República de Colombia, Palabras del Presidente Juan Manuel Santos en la inauguración de la intersección vial La Fuente, Manizales, 4 March 2017, http://es.presidencia.gov.co/sitios/ busqueda/discursos/170304-Palabras-del-Presidente-Juan-Manuel-Santos-en-la-inauguracion-de-la-interseccion-vial-La-Fuente/Discursos. 
the problem of state capture, Santos proposed legislation that would 'permit to regulate lobbying' and the reformation of the electoral system so that private actors could not control the political process through campaign financing. ${ }^{48}$ According to Santos, 'the cost of (electoral) campaigns ha[d] generated a whole dynamic of corruption and misuse of democracy' ${ }^{49}$ In January 2017, following the Odebrecht corruption scandal, Santos would recommend that the state should be the only source of financing for electoral campaigns to prevent that the 'public office is used to serve private economic interests'. ${ }^{50}$

This logic was also reflected in the Colombian Anti-Corruption Statute of 2011, which provided numerous policies to regulate the interaction between the private and the public sector. Many of the anti-corruption regulations aimed to prevent state capture by private actors. The Anti-Corruption Statute sought to 'limit financial contributions to political campaigns by contractors that belong to the private sector, in order to avoid "the capture" of state agents by their [financial] contributors' ${ }^{51}$ It also regulated the employment of former public servants in the private sector, in order to 'stop the abuse of the revolving doors' ${ }^{52}$ Article 3 of the Anti-Corruption Statute stipulated that former public servants could not manage private interests, directly or indirectly, when such interests related to the position the aforementioned public servant occupied in the past. ${ }^{53}$ Such provisions aimed to prevent former public officials such as ministers or deputy ministers from representing private companies in their respective sectors (especially mining and energy) once they left office.

\section{The Definition of Corruption. Narrow versus Broad Understandings of Corruption}

The comparison developed so far hints at another important difference between the two discourses: the definition of corruption. In Rama's discourse

48 The Speech of President Santos at the ceremony where the new General Attorney Fernando Carillo was sworn into office.

49 The Speech of President Santos at the electoral forum 'On the Path to Peace', in: Presidencia de la República de Colombia, Palabras del Presidente Juan Manuel Santos en el foro electoral ‘En la ruta de la paz', Cartagena, 24 March 2017, http://es.presidencia.gov.co/sitios/ busqueda/discursos/170324-Palabras-del-Presidente-Juan-Manuel-Santos-en-el-foro-electoralEn-la-ruta-de-la-paz/Discursos.

50 Santos propone financiación estatal de las campañas, El Espectador, 17 January 2017, http:// colombia2020.elespectador.com/politica/santos-propone-financiacion-estatal-de-las-campanas.

51 Secretaria de Transparencia, Estatuto Anticorrupcion Ley 1474 de 2011. Avances y desafíos tras cinco años de su expedición, 18.

52 Secretaria de Transparencia, Estatuto Anticorrupcion Ley 1474 de 2011. Avances y desafíos tras cinco años de su expedición, 9.

53 Secretaria de Transparencia, Estatuto Anticorrupcion Ley 1474 de 2011. Avances y desafíos tras cinco años de su expedición, 9. 
corruption was defined almost exclusively as bribery since it was strictly tied to the public sector. His anti-corruption strategies aimed at offering better public services so as to produce a 'great liberation from the nightmare of briberies and the nightmare of corruption that for so many years has afflicted people in Albania'. ${ }^{54}$ Corruption according to Rama brought to mind images of a desk with a 'lazy and parasitic public official where the bribe is solicited' ${ }^{55}$ By corruption Rama meant the high levels of bribery within the Albanian judiciary where 'there is a corporation that sells and buys justice: the corporation of the corrupt attorneys and judges of this country'. ${ }^{56}$ Corruption also implied bribes that citizens paid to the employees of the Albanian Energy Corporation (KESH) in order not to pay their energy bills. ${ }^{57}$ Finally, corruption also appeared in the bribes that the police received, which made it difficult to fight the marijuana trade. ${ }^{58}$

Alternative and broader definitions of corruption such as state capture, clientelism, or as a moral, ethical and cultural problem, were almost completely absent in Rama's discourse. He insisted that corruption had almost exclusively to do with a structure of incentives that enabled bribery so that there was no cultural dimension to it:

'Corruption is not an Albanian or Balkan phenomenon. It is completely wrong to think that Albanians or Balkan people by nature are more corruptible than the Germans or the French. Let us bring over 50 Germans from the German public administration and send them to some of the unmodernised structures of our system and let us wait 41 days. [...] On the $41^{\text {st }}$ day I guarantee that there will be no German that has not been Balkanised or Albanianised. In the same way that if we send 50 Albanians or Balkan people to Germany, even if they spent their entire life in Albania or the Balkans, they will never ask for a bribe [...].'59

54 The Speech of Prime Minister Edi Rama at the conference 'The Passport, Your Safety in Electronic Services'.

55 The Speech of Prime Minister Edi Rama at the conference 'The Passport, Your Safety in Electronic Services'.

56 The Speech of Prime Minister Edi Rama at the forum 'Reforming the Judiciary System in Albania', in: Kryeministra (Prime Minister's Office), T'i japim fund diktaturës së korrupsionit të pamëshirshëm të drejtësisë, Tirana, 6 October 2014, https://kryeministria.al/newsroom/ ti-japim-fund-diktatures-se-korrupsionit-te-pameshirshem-te-drejtesise/.

57 The Speech of Prime Minister Edi Rama at the National Forum Against Corruption, in: Kryeministra (Prime Minister's Office), Modernizimi i shtetit, rruga kundër korrupsionit, Tirana, 10 December 2014, https://kryeministria.al/newsroom/modernizimi-i-shtetit-rruga-kunder-korrupsionit/.

58 The Speech of Prime Minister Rama in the presentation of the New National Plan to Combat Cannabis, in: Kryeministra (Prime Minister's Office), Plan i ri Kombëtar në luftën antikanabis, Tirana, 3 March 2017, https://kryeministria.al/newsroom/plan-i-ri-kombetar-neluften-antikanabis/.

59 The Speech of Prime Minister Edi Rama in the second international conference 'Electronic Building Permits for a More Competitive Region', in: Kryeministra (Prime Minister's Office), Lejet e ndërtimit online, modernizim sistemit dhe kundër korrupsionit, 
What is interesting in the above citation is that Rama acknowledged that there was a problematic Albanian or Balkan culture, hence the process of 'balkanisation' or 'albanianisation'. Such culture had, however, nothing to do with the incidence of corruption that in the above citation explicitly refers to bribery. What is important is that the system, i.e. public institutions, should be structured in such a way so as to disincentivise the possibility of bribery by public servants.

The definition of corruption as bribery was quite dominant in Santos' discourse as well. Indeed a central part of his anti-corruption strategy was the approval of the Anti-Bribery Law. ${ }^{60}$ Like Rama he also argued that in order to eliminate corruption one had to reform public institutions to 'make transparent the process of public procurement, improve mechanisms of accountability, simplify processes and reduce this jungle of paperwork in which the corrupt make their nest' ${ }^{61}$ As part of this process, Santos' government produced the Presidential Decree No 1674, 21 October 2016, on Politically Exposed Persons that would allow financial controls over people in position of public power. ${ }^{62}$

Santos however, saw corruption as more than simply bribery. It also included state capture, clientelism, as well as cultural, moral and ethical failures. Hence, its elimination not only called for modernisation of state institutions, but also for ethical, cultural and electoral transformations. In order to eliminate corruption in the public sector, for example, it was necessary to enroll the most ethical citizens in the public service who were committed to the public interest. According to Santos, '[t]o be a public servant should be synonymous with commitment to the general good, a task that calls upon the best and the most ethical citizens to work in the service of their country.' ${ }^{63}$ In order to create such ethical citizens, it was important to create a culture of legality and respect for the rule of law and the public good. According to Santos, this meant that:

Tirana, 6 May 2016, https://kryeministria.al/newsroom/lejet-e-ndertimit-online-modernizim-sistemit-dhe-kunder-korrupsionit/.

60 The Speech of President Santos at the Concordia America Summit, in: Presidencia de la República de Colombia, Palabras del Presidente Juan Manuel Santos en la Clausura del 'Concordia Americas Summit', Bogota, 21 February 2017, http://es.presidencia.gov.co/ sitios/busqueda/discursos/170221-Palabras-del-Presidente-Juan-Manuel-Santos-en-la-Clausura-del-Concordia-Americas-Summit/Discursos.

61 The Speech of President Santos on the approval of the Anti-Corruption Statute.

62 The Speech of President Santos in the Third Regional Dialogue of Open Government Policy in Latin America and the Carribean, in: Presidencia de la República de Colombia, Palabras del Presidente Juan Manuel Santos en el Tercer Diálogo Regional de Política de Gobierno Abierto en América Latina y el Caribe, Bogota, 13 October 2016, http://es.presidencia.gov.co/sitios/busqueda/discursos/161013-Palabras-del-Presidente-Juan-Manuel-Santos-en-el-Tercer-Dialogo-Regional-de-Politica-de-Gobierno-Abierto-en-America-Latina-y-el-Caribe/Discursos.

63 Presidencia de la República de Colombia, Acceptance Speech of Juan Manuel Santos. The Time of Colombia in Now!. 
'The state, parents, schools, higher education institutions and universities, churches and mass media enterprises [...] All have the duty to promote-through teaching and above all by example-a culture of values and respect for the law, without which there can be no worthy anti-corruption strategy.' ${ }^{\prime 64}$

Here corruption was not simply an institutional or public sector problem. It was above all a cultural problem that not only affected the state but society as a whole. More than the incentive structures within public institutions, its primary cause was a culture of 'moral laxity that does NOT allow [Colombia] to progress as society' ${ }^{65}$ In other words and besides being an administrative issue, corruption was also a cultural and ethical phenomenon.

The broad definition of corruption as a cultural problem was also reflected in Colombia's anti-corruption strategies. Unlike, Rama's anti-corruption strategy that aimed almost exclusively to reform the public sector, one of Santos' key priorities of his anti-corruption strategy was to 'consolidate the culture of legality and promote integrity as a principle of individual and collective action in the country'. ${ }^{66}$ In this context the Ministry of Education of Santos' government produced a 'Curriculum of Legality' and undertook various programmes such as 'Goodbye to cheating' and 'Legal tales', targeting children between the ages of 6 and 16 years. ${ }^{67}$ The main aim of these efforts was to incorporate topics on integrity and a culture of legality into the curriculum of formal education. ${ }^{68}$

\section{A Quantitative Comparative Analysis of the Usage of the Concept of Corruption between Rama and Santos}

In order to provide a more accurate overview of the differences between the Albanian and Colombian official discourses on corruption, a quantitative analysis of the usage of the concept corruption in Rama's and Santos' discourses is provided in Table 4 . Table 4 shows the frequency with which Rama and Santos articulated corruption as a public, private or public-private sector problem.

As the Table 4 shows the discourses have much more in common than what might appear from the comparison so far. In trying to emphasis their differences, their commonalities have been underplayed. In both discourses corruption is seen primarily as a phenomenon that pertains to the public sector. In Santos' discourse however, there is a much higher percentage of corruption as a cultural or social phenomenon compared to Rama's discourse, which articulates corruption as an overwhelmingly public sector problem.

\footnotetext{
64 The Speech of President Santos on the approval of the Anti-Corruption Statute.

65 The Speech of President Santos on the approval of the Anti-Corruption Statute.

66 CONPES, Estrategia Nacional de la Pólitica Pública Integral Anticorrupción, 67.

67 CONPES, Estrategia Nacional de la Pólitica Pública Integral Anticorrupción, 48.

68 CONPES, Estrategia Nacional de la Pólitica Pública Integral Anticorrupción, 68.
} 
Table 4. Articulations of corruption in the discourses of Santos and Rama, 2010-2017.

\begin{tabular}{|l|c|c|}
\hline Head of Government & Juan Manuel Santos & Edi Rama \\
\hline Public sector corruption & $30 \%$ & $56.5 \%$ \\
\hline Private sector corruption & $6.7 \%$ & $4.7 \%$ \\
\hline Public-private corruption & $10 \%$ & $9.8 \%$ \\
\hline Cultural corruption & $20 \%$ & $3.2 \%$ \\
\hline None & $33.3 \%$ & $25.8 \%$ \\
\hline
\end{tabular}

Source: Compilation of the author.

\section{Accounting for the Differences. The Ideological Function of Corruption}

It is important to eliminate three tempting explanations as to why official corruption discourses in Albania and Colombia differ. First, one could reasonably argue that if Rama focused on bribery and public sector corruption more than Santos, it was because public sector corruption in Albania was perceived to be higher than in Colombia. Second, one could argue that public sector corruption was actually higher in Albania than Colombia. Finally, one could argue that different articulations of corruption responded to different anti-corruption contexts. While anti-corruption had been a priority of the Albanian government since 1998, in Colombia this issue had been overshadowed by the armed conflict. It was only after the signing of the peace agreement with the FARC in 2016 that Santos' government began to focus on anti-corruption as a key priority. Hence, the fact that Santos' discourses focused on a broader range of issues with regard to corruption could be understood as a reflection of the fact that Colombia's anti-corruption was a more recent phenomenon that still had to develop the legal framework, which Albanian anti-corruption practice already had established.

While both explanations are reasonable they are not born out of the facts. First, there seems to be no mayor difference with regard to corruption perceptions regarding the public sector in either of the countries. As Table 5 demonstrates, perceptions of public sector corruption were quite similar in the two countries. Indeed, in 2013 public sector corruption was a slightly greater concern for Colombians than for Albanians. At the same time, survey data showed that private corruption issues such as state capture were not more salient among the Colombian electorate compared to the Albanian one. Quite to the contrary, more Albanians seemed to think that their government was run by a few large entities acting in their own interests (see Table 6). One cannot conclude therefore, that the official corruption discourses differ because they reflect different corruption preoccupations in the two countries. The same holds true as far as other indices of public sector corruption are utilised. The most famous of such 
Table 5. To what extent corruption is a problem in the public sector? (2013).

\begin{tabular}{|l|c|c|c|c|c|c|}
\hline \multicolumn{1}{|c|}{$\begin{array}{c}\text { Category } \\
\text { Country }\end{array}$} & $\begin{array}{c}\text { Not at all } \\
\text { a problem } \\
1\end{array}$ & 2 & 3 & 4 & $\begin{array}{c}\text { A very seri- } \\
\text { ous problem } \\
5\end{array}$ & $\begin{array}{c}\text { Aggregate } \\
\text { Score }\end{array}$ \\
\hline Albania & $1 \%$ & $6 \%$ & $14 \%$ & $30 \%$ & $50 \%$ & 4.2 \\
\hline Colombia & $2 \%$ & $3 \%$ & $13 \%$ & $21 \%$ & $62 \%$ & 4.4 \\
\hline
\end{tabular}

Source: Transparency International, In Detail. Global Corruption Barometer 2013. Data and Methodology, http://www.transparency.org/gcb2013/in_detail.

Table 6. To what extent is this country's government run by a few big entities acting on their own best interest? (2013).

\begin{tabular}{|l|c|c|c|c|c|c|}
\hline & Not at all & $\begin{array}{c}\text { Limited } \\
\text { Extent }\end{array}$ & Somewhat & Large extent & Entirely & $\begin{array}{c}\text { Aggregate } \\
\text { Score: Large } \\
\text { extent and } \\
\text { entirely }\end{array}$ \\
\hline Albania & $1 \%$ & $8 \%$ & $25 \%$ & $38 \%$ & $28 \%$ & 66 \\
\hline Colombia & $8 \%$ & $9 \%$ & $23 \%$ & $27 \%$ & $32 \%$ & 59 \\
\hline
\end{tabular}

Source: Transparency International, In Detail. Global Corruption Barometer 2013.

Table 7. Corruption Perception Index (CPI) for Albania and Colombia 2012-2017.

\begin{tabular}{|l|c|c|c|c|c|c|c|}
\hline Country & 2012 & 2013 & 2014 & 2015 & 2016 & 2017 & Average \\
\hline Albania & 33 & 31 & 33 & 36 & 39 & 38 & 35.0 \\
\hline Colombia & 36 & 36 & 37 & 37 & 37 & 37 & 36.7 \\
\hline
\end{tabular}

Source: Transparency International, Corruption Perception Index. Overview 2017, https://www. transparency.org/research/cpi/overview.

indices, the Corruption Perception Index (CPI) by Transparency International, could be utilised as a proxy for measuring levels of public sector corruption (see Table 7). As Table 7 shows, there is a very little difference between Albania and Colombia as far as the CPI is concerned. Although it is very difficult to measure actual levels of corruption in the public sector, another possible proxy estimation could be the level of bribery in the public sector. As Table 8 shows, although levels of bribery appear to be slightly higher in the Albanian public sector, there is very little difference between the two countries. The same holds true regarding anti-corruption legislation. While Albania began its anticorruption crusades earlier, the Global Integrity Index showed that Colombia's anti-corruption legislative framework in 2011 was more comprehensive than 
Table 8. Experience with bribery in the past 12 months in public services 2016-2017.

\begin{tabular}{|l|c|c|}
\hline Country & $\begin{array}{c}\text { Percentage of respondents that reported paying a bribe } \\
\text { when accessing public services }\end{array}$ & Year \\
\hline Albania $^{\mathrm{a}}$ & $34 \%$ & 2016 \\
\hline Colombia $^{\mathrm{b}}$ & $30 \%$ & 2017 \\
\hline
\end{tabular}

Source: Transparency International: Global Corruption Barometer 2015/16/17. ${ }^{a}$ Transparency International, People and Corruption. Europe and Central Asia 2016, 16, https://www.transparency. org/whatwedo/publication/people_and_corruption_europe_and_central_asia_2016. ${ }^{\mathrm{b}}$ Transparency International, People and Corruption. Latin America and the Caribbean 2017, 15, https:// www.transparency.org/whatwedo/publication/global_corruption_barometer_people_and_corruption_latin_america_and_the_car.

that of Albania in $2010 .{ }^{69}$ In other words, one could not argue that the difference in corruption discourses can be explained due to the different anti-corruption stages of the two countries.

What explains the differences in the two discourses is not some 'corruption reality' on the ground, but the dominant neoliberal ideological context within which corruption was articulated. Here, neoliberal ideology is understood as a discourse that views the market as the primary engine of development and advocates open markets and free trade, while seeking to 'adopt the free market as an organizing and regulating principle of the state'. ${ }^{70}$ Hence, the term neoliberal is used to identify a range of governmental projects aiming 'to corporatize or privatize public sector institutions, to expand the sphere of competition and market like interaction'.$^{71}$ Both countries have been transformed and penetrated by such a neoliberal ideology, albeit to different extents. The neoliberal order began to shape Colombian governance as early as the late 1970s. ${ }^{72}$ In Albania a similar process began in earnest from 1992, after the fall of communism. ${ }^{73}$

Although the neoliberal ideology is dominant in both countries, it has different nuances in each case. The neoliberal ideology in Albania glorifies the market as the ultimate solution to all socio-political problems, without recognising any possible market failures. In the Colombian case the neoliberal ideology is 'softer' insofar as it is interpreted in the Third Way ideology. Of course, the Third Way ideology can be best described in the words of Perry Anderson as

69 Global Integrity. Data, Learning and Action for an Open Government, The Global Integrity Report (2011), https://www.globalintegrity.org/research/reports/global-integrity-report/ global-integrity-report-2011.

70 Michele Foucault, The Birth of Biopolitics, New York 2004, 116.

71 Hindess, Investigating International Anti-Corruption, 1389-1398, 1390.

72 Jairo Estrada Alvarez, ed, Construcción del Modelo Neoliberal en Colombia 1970-2004, Bogota 2004, 65.

73 Blendi Kajsiu, ed, A Discourse Analysis of Corruption. Instituting Neoliberalism Against Corruption in Albania, 1998-2005, London 2015, 102. 
'the ideological shell of neoliberalism' ${ }^{74}$ Under this ideology, the New Labour in Britain 'embraced the market with a passion and enthusiasm which often [left] the Conservatives standing. ${ }^{.75}$ However, the Third Way, at least pays lip-service to left-wing concepts such as social justice, while recognising some limits to the market and some benefits to state intervention. In this sense it is 'softer' than the neoliberalism of the Chicago School that always views market failures as better than any failure caused by the very state intervention that sets out to correct them. It is this latter kind of neoliberal fundamentalism that is dominant in Albania today.

The difference between the two countries is that while in Colombia there has been resistance to the dominant neoliberal ideology, in Albania such resistance has been almost completely absent, at least within the main political parties. In the Colombian case, there are important parties on the left, such as El Polo Democratico Alternativo that forcefully condemn and resist neoliberalism and globalisation:

‘We [El Polo Democratico Alternativo] defend the sovereignty and independence of our nation against the United States and any other foreign centre of power. We reject the neoliberal globalisation and its instruments, Free Trade Treaties (FTT), as well as the impositions of big financial capital and its international institutions of control, the World Bank, the International Monetary Fund and the World Trade Organization. ${ }^{76}$

Even right-wing politicians such as Alvaro Uribe who have been instrumental in the implementation of a neoliberal order in Colombia have had to pay lipservice to the criticism of neoliberalism. In his 2002 electoral manifesto Uribe, President of Colombia from 2002 to 2010, declared that the '[n]eoliberal model abandoned the social at the mercy of the market, which increased social misery and injustice' ${ }^{77}$ To this end, Uribe proposed the Communitarian State as an alternative between the populist left and the neoliberal right. In a similar fashion Santos, who succeeded Uribe in 2010, embraced the Third Way as the alternative to socialism and neoliberalism. ${ }^{78}$

74 Perry Anderson, Renewals, New Left Review 1 (2000), 1-20, 7, https://newleftreview.org/ II/1/perry-anderson-renewals.

${ }^{75}$ Ian Ferguson, Neoliberalism, the Third Way and Social Work. The UK Experience, Social Work and Society 2, no. 1 (2004), 1-9, 4, https://www.socwork.net/sws/article/view/236/411.

76 Polo Democratico Alternativo, Ideario de Unidad. Por una Colombia digna, democrática y soberana. Third National Congress, Bogota, 9-10 November 2012, 1, https://www.polodemocratico.net/pdf/IDEARIO\%20DE\%20UNIDAD.pdf bid.173zation, p.018)

77 Alvaro Uribe Velez, Manifiesto Democratico - 100 Puntos Alvaro Uribe Velez, Bogota 2002, https://www.mineducacion.gov.co/1759/1621/articles-85269_archivo_pdf.

78 The Speech of President Santos in the presentation of the work on housing and infrastructure, in: Presidencia de la República de Colombia, Palabras del Presidente Juan Manuel Santos en el balance del sector de infraestructura y vivienda, Bogota, 14 March 2017, http:// 
This is not to say that there is a dominant left-wing ideology in Colombia. In fact, Colombia is one of the most right-wing countries in Latin America. ${ }^{79}$ There is, nevertheless, a willingness within the dominant neoliberal ideology of Colombia to recognise the limits of the market and the necessity of state intervention. Such willingness is in part a reflection of the resistance to the neoliberal model from various political and civil society sectors in Colombia. This in turn is reflected by the fact that there are clear ideological and policy differences between left- and right-spectrum political parties in Colombia, that is between the Democratic Pole (El Polo Democratico) on the left and the liberal and conservative parties on the right, as well as between the conservative and the centre democratic party, which is still further to the right. ${ }^{80}$

Hence, Santos' discourse on corruption is shaped by his Third Way ideology, meaning that his government is

'friends to the private enterprises, to free trade [...] We believe in the benefits of foreign investment and we protect it, so much so that the World Bank ranks us as the country that is most friendly to investors in Latin America' ${ }^{81}$

It is an ideology that while prioritising the market also incorporates criticisms of the neoliberal project, recognising the limits of the market and the need for state intervention when necessary. It 'seeks to allow market laws to function as far as possible and permit state intervention only when necessary, in order to guarantee greater equity and give opportunities to the vulnerable population' ${ }^{82}$ In this context it is no surprise that corruption within this discourse appears as a phenomenon, while primarily present in the public sector can also be found in the private one.

By contrast there is no similar criticism of the neoliberal ideology among the Albanian political parties. Albania is a rather peculiar case in Eastern Europe as one of the few countries where it is impossible to find the 'red-brown' ideology that combines the anti-capitalist ideology of the left with the nationalist rhetoric of the right. ${ }^{83} \mathrm{~A}$ traumatic communist past has prevented the emergence of right- or left-wing political parties that could challenge the dominant neoliberal hegemony, which since 1992 was legitimised as the very opposite of commu-

es.presidencia.gov.co/sitios/busqueda/discursos/170314-Palabras-del-Presidente-Juan-Manuel-Santos-en-el-balance-del-sector-de-infraestructura-y-vivienda/Discursos.

79 Juan Carlos / Raga Rodriguez, Izquierda y Derecha en Colombia. Una mirada rápida a los rasgos sociodemográficos del espectro ideologico del país, Colombia Internacional 66 (2007), 184-193, 185, DOI: 10.7440/colombiaint66.2007.10.

80 Carlos / Rodriguez, Izquierda y Derecha en Colombia, 186-187.

81 The Speech of President Santos in the presentation of the work on housing and infrastructure.

82 The Speech of President Santos in the presentation of the work on housing and infrastructure.

${ }^{83}$ Kajsiu, Polarization without Radicalization, 288. 
nism. ${ }^{84}$ In part due to their traumatic communist past, Albanians are among the most enthusiastic supporters of liberalisation and globalisation in Europe, with the highest levels of support for globalisation compared to other countries in its region such as Bulgaria, Romania, Greece and Turkey and the EU average. ${ }^{85}$ This in turn has meant that both major political parties, the democratic and the socialist parties, have pursued neoliberal policies and differ very little, if at all, in ideological terms. ${ }^{86}$ The policy distance regarding EU integration in 2008 between the two main parties in Albania, was smaller than in Romania, Bulgaria, Serbia, Slovakia and many other Eastern European countries. ${ }^{87}$

It is within this dominant neoliberal ideology that one should understand Rama's articulation of corruption as primarily an administrative phenomenon that it is limited to the public sector. Such articulation reflects and reproduces the dominant neoliberal development model that sees the market as the primary engine of progress and the state as the mayor obstacle in its way. According to Rama, corruption is not inherent to the private sector. This is not to say that all entrepreneurs are honest, but that even the dishonest ones are a product primarily of state intervention:

'The image of the businessmen as a thief, a robber, as someone dubious, has not been created only by that part of the business community that has acted accordingly, but has primarily been created by the aggressive, arrogant and thieving behaviour of the state in its relation to the business sector [author's emphasis]. ${ }^{88}$

From this perspective the government should empower private businesses in order to contain the abuses of the state. The public-private partnership 'offers a valuable assistance in order to create sound systems of financial administration in the transition or emerging markets. ${ }^{89}$ The reason why such partnerships reduce corruption is due to 'the strict demand of the private partner that the money it invests should be managed in the best manner possible, something

84 Kajsiu, Polarization without Radicalization, 288.

85 European Commission, Standard European Barometer 82. Autumn 2014. First Results, December 2014, 169, http://ec.europa.eu/commfrontoffice/publicopinion/index.cfm/Survey/ getSurveyDetail/yearFrom/2013/yearTo/2014/search/82/surveyKy/2041.

86 Roland Lami / Aleksander Kocani, eds, Identity of the Political Parties in Albania during the Period 1990-2013, Saarbrücken 2015, 66.

87 Lenka Bustikova, Revenge of the Radical Right, Comparative Political Studies 47, no. 12 (2014), 1738-1765, DOI: 10.1177/0010414013516069.

88 The Speech of Prime Minister Edi Rama with employees of the tax administration, in: Kryeministra (Prime Minister's Office), Transformim rrënjësor i marrëdhënies së administratës tatimore me tatimpaguesit, Tirana, 19 January 2014, https://kryeministria.al/newsroom/ transformim-rrenjesor-i-marredhenies-se-administrates-tatimore-me-tatimpaguesit/.

89 The Speech of Prime Minister Edi Rama in the presentation of the cooperation programme with the USAID for the improvement of the efficiency of the tax administration, in: Kryeministra (Prime Minister's Office), Rritja e efiçencës së administratës tatimore, Tirana, 18 February 2016, https://kryeministria.al/newsroom/rritja-e-eficences-se-administrates-tatimore/. 
that state structures neither today nor in the future can achieve. ${ }^{90}$ It is through cooperation with the private sector, as a superior partner-both in terms of efficiency and honesty - that the public sector can be improved. This is a highly ideological statement that is entirely contrary to the colossal corruption cases through public-private partnerships in the USA and Colombian healthcare systems.

It is important to emphasise here that the ideological context, especially in small and poor countries like Albania, is determined not only by local factors but also by the intervention of powerful international institutions. In Albania the intervention of international organisations such as the World Bank, the Council of Europe and the United States Agency for International Development (USAID), especially during the period from 1998 to 2005, transformed corruption from a signifier that stood for a variety of economic, social, moral and political failures into a very specific phenomenon that was defined as 'abuse of public office for private gain' and in practice identified primarily with bribery in the public sector. ${ }^{91}$ Since then, both 'left-wing' socialist party governments (1998-2005) and the right-wing democratic party governments (2005-2013) have articulated a discourse of corruption that has served to legitimise a number of neoliberal policies, such as the privatisation of public assets and the marketisation of services including education and healthcare. ${ }^{92}$

As of 2017, there has been no comparable intervention in Colombia. This is not to say that articulations of corruption in Colombia have not been heavily influenced by international institutions such as the World Bank or the Organization for Economic Cooperation and Development, whose definitions of corruption have become part of Colombian legislation. Nevertheless, unlike in the case of Albania, international intervention in Colombia has not focused on anti-corruption as much as on the war against drugs and armed subversion. In other words, while the major international intervention during the 1998-2005 period in Albania was focused on anti-corruption, during the same period, 1999-2002, in Colombia such intervention focused on Plan Colombia-a 1.3 billion dollar US military aid package to the Colombian military in order to wage a war against drugs and the left-wing 'narco-guerrillas'. ${ }^{93}$ As a consequence, the dominant neoliberal articulation of corruption as primarily a public sector disease, promoted especially by international institutions such as the World

90 The Speech of Prime Minster Edi Rama at the opening ceremony of the private hospital Continental Investment in: Kryeministra (Prime Minister's Office), Private në shëndetësi, më shumë konkurrencë dhe cilësi, Tirana, 26 October 2016, https://kryeministria.al/newsroom/ investimet-private-ne-shendetesi-me-shume-konkurrence-dhe-cilesi/.

${ }^{91}$ Kajsiu, A Discourse Analysis of Corruption, 172-173.

92 Kajsiu, A Discourse Analysis of Corruption, 172-173.

93 Doug Stokes, Better Lead than Bread? A Critical Analysis of US' Plan Colombia, Civil Wars 4, no. 2 (2001), 59-78, 1, DOI: 10.1080/13698240108402469. 
Bank, the USAID or the International Monetary Fund (IMF), was not as dominant in Colombia as it was in Albania.

\section{Conclusion}

In this paper I have compared and contrasted the two official discourses on corruption focusing on the speeches and anti-corruption policies of prime minister Edi Rama in Albania and president Juan Manuel Santos in Colombia during the period 2010-2017. I have tried to point out that there are three key differences in the articulation of corruption between Santos and Rama. First, in Rama's discourse corruption is located primarily within the public sector in general and the state in particular, while it seems quite absent from the private sector. In Santos' discourse on the other hand, corruption can be found both in the private and the public sector, as well as in the interaction between the two. Second, while in Rama's discourse the state is the principal perpetrator of corruption and the private companies and citizens its primary victims, Santos articulates corruption as also perpetrated by private and social actors against the state. Finally, corruption is defined quite narrowly in Rama's discourse as bribery, whereas Santos defines corruption more widely as a cultural, ethical, moral and political phenomenon.

I have argued that such different articulations do not correspond to different types of corruption or anti-corruption 'realities' on the ground. Rather, they reflect two different ideological contexts that shape the articulation of corruption. In Santos' discourse the articulation of corruption is a reflection in his Third Way ideology, which while prioritising the market, also incorporates criticisms of the neoliberal project, thereby recognising the limits of the market and the need for state intervention when necessary. Rama's articulation of corruption as an almost exclusively public sector phenomenon, on the other hand, reflects his dominant neoliberal ideology that sees the private sector as the engine of development and the state as a potential hindrance. In both cases, the discourse of corruption does not simply reflect corruption realities on the ground, but serves to constitute the public sector in general and the state in particular from a very specific ideological standpoint. In other words, as Gupta has pointed out in the case of India, 'the discourse of corruption turns out to be a key arena through which the state, citizens, and other organizations and aggregations come to be imagined. ${ }^{94}$ This is why, instead of focusing on corruption only as a problem that should be overcome, it is important to 'see it as a mechanism

94 Akhil Gupta, Blurred Boundaries. The Discourse of Corruption, the Culture of Politics, and the Imagined State, American Ethnologist 22, no. 2 (1995), 375-402, 376, http://www.jstor. org/stable/646708. 
through which "the state" itself is discursively constituted'.$^{95}$ As I have tried to show in this paper, such discursive construction has an important ideological dimension, especially at the elite level.

As corruption slowly becomes a central topic of debate in Colombia following the 2016 peace agreement with the FARC, it is likely that international institutions such as the World Bank, the IMF, or the USAID will become more fully involved in its anti-corruption programmes. Judging from the Albanian experience, it is likely that such interventions will produce a more narrow and economic understanding of corruption, where it will become primarily located in the public sector. In that case, it will be important to keep in mind that corruption is an ideologically laden concept that gives rise to anti-corruption policies that are not simply technical solutions to the 'reality' of corruption. Corruption and anti-corruption discourses are arenas through which local and international institutions ideologically constitute the state, the public and the private sphere.

\section{CORRESPONDING AUTHOR}

Blendi Kajsiu University of Antioquia, Faculty of Law and Political Science, Bloque 14, Oficina 14-404, Cl. Barranquilla 53-108, 050010 Medellin, Colombia. E-mail: blendi.kajsiu@udea.edu.co

95 Gupta, Blurred Boundaries. 